\title{
Burlington Resources Inc. v. Republic of Ecuador: a landmark decision in environmental counterclaims
}

\author{
María Soledad Peña Plaza* \\ Recibido/Received: 02/05/2019 \\ Aceptado/Accepted: 06/05/2019
}

Summary: 1. Introduction. 2. Counterclaims under International Investment Treaties. 2.1 Basis for a tribunal to hear counterclaims. 2.1.1 Treaty provisions. 2.1.2 Theory of the applicable law clause as a basis to admit counterclaims. 2.1.3 Reference to counterclaims in applicable arbitration rules. 2.1.4 Consent. 2.2 Basis for allowing Ecuador's counterclaims in Ecuador v. Burlington. 3. The Burlington v. Ecuador Case. 3.1 Historical background. 3.2 Ecuador's change in Production Sharing Contracts. 4. Environmental counterclaims. 4.1 The 2008 Constitution: a protectionist regime towards the environment. 4.2 Legal Framework to resolve environmental counterclaims. 4.3 Liability in environmental claims. 4.3.1 Meaning of environmental harm. 4.4 Reparation of damages in environmental claims. 5. Ecuadorian BIT models: broader protection for the environment. 6. Conclusion.

AвstRact: The Burlington Resources Inc. v. Republic of Ecuador counterclaims case turned into a landmark decision, being the first case in which an ICSID tribunal had fully admitted a counterclaim on the merits and, held an investor liable for environmental damages within the frame of a BIT. The present article is intended

\footnotetext{
* Masters of Law in International Business and Economic Law, Certificate in International Arbitration and Dispute Resolution, Georgetown University, 2019. Lawyer Universidad Católica de Santiago de Guayaquil, 2017. E-mail:mp1612@georgetown.edu
}

M. S. PeÑa PlazA, "Burlington Resources Inc. v. Republic of Ecuador: a landmark decision in environmental counterclaims", Revista Ecuatoriana de Arbitraje, No. 10, 2019, pp. 233-265. 
to analyze: (i) the different basis under which Tribunals have deemed themselves competent to hear a counterclaim in the legal framework of a BIT; (ii) the sui generis nature of admitting jurisdiction based in a compromise by the Burlington tribunal; and, (iii) the new Ecuadorian Model of Investment Treaty based on the recent Investment Treaty's Tribunal decisions that are allowing States adequate relief by permitting protection of the environment and human rights of Host Countries. Discussion and criticism about the first ICJ decision awarding damages for a violation of international environmental law have also been brought under the light of this article.

KeYwords: counterclaims, compromise, Bilateral Investment Treaty, Host Countries, damages, environmental harm, precautionary principle.

\section{Burlington Resources Inc. v. República del Ecuador: una decisión histórica en reconvenciones ambientales}

Resumen: Las reconvenciones del caso Burlington Resources Inc. v. República del Ecuador se convirtieron en una decision histórica, siendo este el primer caso en el cual un tribunal CIADI admitió completamente una reconvención en méritos, y encontró responsable al inversor por daños ambientales dentro del marco de un TBI. El presente artículo tiene la intención de analizar: (i) las distintas bases bajo las cuales los tribunales se han considerado competentes para conocer una reconvención bajo el marco legal de un TBI; (ii) la naturaleza sui generis de la admisión de jurisdicción basada en un compromiso por el tribunal del caso Burlington; y, (iii) el nuevo modelo ecuatoriano de un TBI basado en las decisiones recientes de los tribunales de tratados de inversión que están permitiendo a los Estados adecuar los desagravios al permitir la protección de derechos humanos y ambientales de los Estados sede. 
La discusión y críticas sobre la primera decisión de la CIJ que reconoce daños por la violación de la ley internacional ambiental han sido también traídas a la luz en este artículo.

Palabras clave: reconvenciones, compromiso, Tratado Bilateral de Inversión, países sede, daños, daño ambiental, principio de precaución.

\section{INTRODUCTION}

One of the biggest criticisms and unresolved questions that Investor-State arbitration had been facing is whether or not States have the possibility of raising counterclaims in investment arbitrations. There are opposing views in the academia and within the investment treaty arbitral tribunals regarding the jurisdiction of the arbitral tribunals and the admissibility of counterclaims raised by the States under the frame of an investment treaty ${ }^{1}$. This present discussion has led to contradictory awards ruling on the issue of jurisdiction and admissibility of State's counterclaims. Before deepening in the analysis of Ecuador v. Burlington, there must be analyzed, in the first place: (i) the different positions of arbitral tribunals regarding the admissibility of counterclaims; (ii) the advantages of accepting the counterclaims; and, (iii) the necessity of making it the general rule through the establishment of clear provisions in the International Investment Treaties (onwards, IITs) or International Investment Agreements (onwards, IIAs) in order to rebalance the asymmetry that exists in the InvestorState Dispute Settlement (onwards, ISDS). This first analysis

1. Most of the tribunals and authors, such as in the case of Spyridon Roussalis v. Romania, support the position that if the counterclaim is not expressly permitted in the IIA, IIT or BIT, then consent cannot be implied from the procedural provisions referring to counterclaims in the applicable procedural arbitral rules. However, in the last years, tribunals such as Urbaser S.A. and Consorcio de Aguas Bilbao Bizkaia, Bilbao Bizkaia Ur Partzuegoa v. The Argentine Republic, and Antonio Goetz \& Others and S.A. Affinage des Metaux v. Republic of Burundi, have decided that an express acceptance of ICSID procedural rules, was sufficient to imply a consent to counterclaims; there was not need to locate additional or affirmative consent in the underlying BIT. 
will take us to the conclusion, that in order to survive, the ISDS is condemned to evolve towards a more symmetric, equalized and neutral system for investment disputes resolutions.

One purpose of IITs or IIAs is to correct the imbalance that can exist if a State exercises its power and authority over investors. For achieving this objective, IITs limit State's authority by imposing several obligations to it -and in most treaties, none obligations to the investors-, and by granting the investor the possibility to file arbitration claims against Host States in case of breach of any of those treaty-based duties. This is perfectly logical and understandable, since it is true that in many States it exists an apparent bias on their local courts due to distinct reasons such as lack of separation of power, state immunity, etc. The idea was to provide the parties with a neutral playing field in which they could defend each other in arms' length.

The problem of the asymmetry arises in part due to the lack of obligations imposed to the Investors under the treaties, and even in greater part the issue arises once the arbitration starts because under most IITs or IIAs, States lack the power to submit a claim, and even in many scenarios it is deprived to defend itself with a counterclaim ${ }^{2}$. It must be said that the State not only does not have the chance to seek for affirmative relief from the investor when it does not comply with its domestic laws and regulations, but also -under most treaties that do not allow counterclaims- cannot ask for redress. States can only seek to diminish investor rights, it cannot win, it can just not lose. "Thus, it is certainly true that looking at investment treaty arbitration in isolation, the procedure is usually one sided, and that disequilibrium might be redressed by the ability of States to submit counterclaims against investors" ${ }^{\prime 3}$.

2. A. K. BJoRKLUnd, "The Role of Counterclaims in Rebalancing Investment law", Lewis \& Clark Law Review, 2013, p. 463.

3. Ibídem. 


\section{COUNTERCLAIMS UNDER INTERNATIONAL INVESTMENT TREATIES}

\subsection{Basis for the tribunal to hear counterclaims}

\subsubsection{Treaty provisions}

The arbitration clause provided in IIAs or IITs is considered a unilateral open offer or invitation by the Host State for the investor to seek arbitration. The investor accepts it by filing the claim and instituting the arbitration proceeding under the treaty. However, when the arbitration clause does not contemplate the possibility of counterclaims (and this is the case of the great majority of IITs) it has been considered by the majority of arbitral tribunals that they lack of jurisdiction to admit a counterclaim filed by the Host State. This decision of the tribunal will depend -partly- on the treaty's language regarding the scope of the ISDS4.

There are very few treaties that expressly refer to counterclaims in the provision containing the offer to arbitrate investment disputes where the Investor by commencing arbitration under the treaty consent. "An express reference to counterclaims in the provisions containing the offer to arbitrate investment disputes can turn the balance in favor of asserting jurisdiction over a counterclaim" ${ }^{5}$. For example, one of the few IITs that grants the express right to assert counterclaims to the Host State is the Common Market for Eastern and Southern Africa (COMESA) Investment Agreement, which provides in its article 28 (9):

A Member State against whom a claim is brought by a COMESA investor under this Article may assert as a defence,

4. Ídem, p. 466.

5. D. Atanasova, C. A. Martínez \& J. OSTRANSKY, Counterclaims in Investor-State Dispute Settlement (ISDS) under International Investment Agreement (IIAs), Trade and Investment Law Clinic Papers 2012, The Graduate Institute Centre for Trade and Economic Integration, p. 17. 
counterclaim, right of set off or other similar claim, that the COMESA investor bringing the claim has not fulfilled its obligations under this Agreement, including the obligations to comply with all applicable domestic measures or that it has not taken all reasonable steps to mitigate possible damages ${ }^{6}$.

We must make a parenthesis at this point, to emphasize another interesting and uncommon thing of the COMESA agreement. This IIA expressly imposes obligations to the investor: (i) to comply with all the applicable domestic measures; and (ii) to mitigate any possible damages. It is a very significant advance since, as we mentioned before, most IAAs and IITs do not impose any obligations on the investor and if they do, they are focused on the stage of investmentmaking and not in the post-investment stage as in this one. To clearly state the obligations in a treaty to elevate it to an international obligation, it is a significant advance towards reaching the so needed rebalancing in ISDS, this specific issue will be expanded later on the paper.

On the other hand, there are treaties that address the issue of counterclaims in a more implicit manner, by excluding some particular types of counterclaims. The most common counterclaims that tend to be excluded relate to the recovery of losses by the investor by some guarantee mechanism such an insurance agreement. For example, the Uruguay- US Bilateral Investment Treaty in article 24 (7) provides:

A respondent may not assert as a defense, counterclaim, right of set of, or any other reason that the claimant has received or will receive indemnification or other compensation for all or part of the alleged damages pursuant to an insurance or guarantee contract ${ }^{7}$.

6. Investment Agreement for the COMESA Common Investment Area (2007), Article 28(9). Available at: <https://bit.ly/2LS3Tqe>

7. Uruguay- United States Bilateral Investment Treaty (2006). Available at:

$<$ https://bit.ly/30yzm50> 
This provision is construed contrario sensu, as a permission to allow all other types of counterclaims under the particular IIAs. This argument can be used in favor of the admission of a counterclaim regarding a subject matter not pertaining of the group that is expressly prohibited in the above mentioned article.

In a similar case, NAFTA Chapter 11, established very narrowly the circumstances in which the investor party was entitled to submit arbitration. However, later on, it established that "in an arbitration a party shall not assert, as a defense, counterclaim, right of setoff or otherwise that the disputing investor has received or will receive, pursuant to an insurance or guarantee contract, indemnification or other compensation for all or part of its alleged damages" ${ }^{\prime 8}$. Some took the position that it has no sense to specifically preclude counterclaims in one circumstance unless they were permitted in others". Nevertheless, professor Douglas concluded that if investor's primary claims were limited to breaches of chapter 11, "it would be preferable to construe Chapter 11 of NAFTA as excluding the possibility of counterclaims by the Host State respondent"10. Precisely, this was the argument in which the tribunal in Spyridon Roussalis v. Romania ${ }^{11}$ refused to admit counterclaims against the foreign investor.

\subsubsection{Theory of the applicable law clause as a basis to admit counterclaims}

Some authorities suggest that the applicable law clause in IIAs or IITs might be important to determine if there is availability to submit a counterclaim. Depending on the provisions of the treaty, some will direct tribunals to apply

8. North American Free Trade Agreement (1992), Article 1116.

9. A. K. BJoRKLUND, N. 2, p. 469.

10. Ibídem.

11. Spyridon Roussalis v. Romania, ICSID Case No. ARB/06/1, Award, 12/7/2011. 
the treaty while others will mandate that the domestic law of the Host State will be the governing law of the arbitration. In the first scenario, since it is very unlikely that treaties impose obligations to investors ${ }^{12}$, Host States would not have grounds to bring a claim under the treaty or international law. However, there is the possibility that by applying international law, the tribunal decides to include the rules of international conflict to decide the appropriate law, and thus it can decide that the applicable law to the conduct of the investor would be the Host State' $\mathrm{S}^{13}$. In this case, it would not be necessary to have a treaty obligation of compliance with domestic law to apply it, but still the issue of consent will be hard to overcome. In the latter scenario, allegations of breaches of domestic law by the Host State might have a streamline path to bring it to the investment tribunal.

Another way to bring a counterclaim would be through the application of an umbrella clause. Umbrella clauses allow to elevate a breach of a contract by the government within a contract with a foreign investor to a treaty breach committed by the State. The rationale behind its application is that a failure to honor a contract constitutes a failure to honor the guarantees recognized by the State in a treaty. Consequently, if an investment tribunal was competent to hear all contract-based claims it should be able to hear counterclaims. In other words, "an investment tribunal hearing a claim brought under the umbrella clause will effectively be hearing a breach of contract claim, which suggest counterclaims with respect to the contract would appropriate be heard as well"14. This was the case of the

12. Very few treaties impose obligations to the investor, for instance the new United States, Mexico, Canada, Agreement USMCA, dedicate a whole chapter to environmental regulations and impose obligations to all parties, including investors of the countries, such as in article 24(4): "No Party shall fail to effectively enforce its environmental laws through a sustained or recurring course of action or inaction in a manner affecting trade or investment between the Parties, after the date of entry into force of this Agreement". Available at: $<$ https://bit.ly $/ 207 \mathrm{mJg} 6>$

13. A. K. BJoRKLUND, N. 2, p. 470.

14. Ibídem. 
tribunal in SGS Société Générale de Surveillance S.A. v. Islamic Republic of Pakistan in which the tribunal held:

It would be inequitable if, by reason of the invocation of ICSID jurisdiction, the Claimant could on the one hand elevate its side of the dispute to international adjudication and, on the other, preclude the Respondent from pursuing its own claim for damages by obtaining a stay of those proceedings for the pendency of the international proceedings, if such international proceedings could not encompass the Respondent's claim ${ }^{15}$.

\subsubsection{Reference to counterclaims in applicable arbitration rules}

Many of the procedural rules under which investment arbitrations are held, such as UNCITRAL Arbitration Rules or ICSID Convention, mention the possibility of counterclaims. Therefore, some argue that one of the sources of tribunals competence to admit counterclaims is in the arbitration procedural rules agreed by the parties. The ones that support the argument basically allege that when the parties agree to a set of arbitration procedural rules, they are expressly agreeing to all its provisions including the permission to admit counterclaims. Article 46 of the ICSID Convention provides:

except as the parties otherwise agree, the Tribunal shall, if requested by a party, determine any incidental or additional claims or counterclaims arising directly out of the subject matter of the dispute provided that they are within the scope of the consent of the parties and are otherwise within the jurisdiction of the Centre $^{16}$ (emphasis added).

15. SGS Société Générale de Surveillance S.A. v. Islamic Republic of Pakistan, ICSID Case No. ARB/01/13, Procedural Order No. 2, 10/16/2002, p. 302.

The tribunal also stated that the lack of an express clause in the Claims Settlement Declaration conferring the right to present counterclaims in inter-State cases does not warrant the conclusion that such counterclaims are prohibited, since each Party could file claims against the other.

16. Arbitration Rules of the International Centre for Settlement of Investment Disputes (1966), Rule 40(1). The Convention on the Settlement of Investment Disputes between States and Nationals of other States entered into force on 10/14/1966 and has been ratified by 154 countries. Ecuador denounced the Convention on July 6, 2009. Available at: $<$ https://bit.ly/2nhow1w $>$ 
The first case in which an ICSID tribunal dealt with the conditions for bringing a counterclaim under its rules was Klöckner Industrie-Anlagen $\mathrm{GmbH}$ and others v. United Republic of Cameroon and Société Camerounaise des Engrais ${ }^{17}$. The investor claimant Klöckner brought a contract-based claim against Cameroon under the terms of a joint venture to build a fertilizer plant. Klöckner initiated an ICSID arbitration based on its own contract with Cameroon, which counterclaimed on the bases of two other related contracts including one with the joint venture company. The tribunal "without expressly tying its reasoning to the terms of article 46 of the ICSID Convention that governs counterclaims, found that such a counterclaim could be brought under related agreement because the contract's constituted an indivisible whole"18.

However, the opposing view argues that the provision is a procedural mechanism that would allow the filing of counterclaims only to the extent that the option would be foreseen in the consent instrument itself. The 2010 UNCITRAL rules provide that a tribunal may hear counterclaims provided that it has jurisdiction over them. Article 21(3) reads as follows:

in his statement of defense or a later stage in arbitral proceedings if the arbitral tribunal decides that the delay was justified under the circumstances, the respondent may take a counter-claim or rely on a claim for the purpose of a set off provided that the arbitral tribunal has jurisdiction over it ${ }^{19}$ (emphasis added).

One of the most comprehensive considerations of arbitral jurisdiction over counterclaims under UNCITRAL Rules of

17. Klöckner Industrie-Anlagen GmbH and others v. United Republic of Cameroon and Société Camerounaise des Engrais, ICSID Case No. ARB/81/2.

18. M. A. Clodfelter \& D. Tsutieva, "Counterclaims in Investment Treaty Arbitration", in K. YANnaCa-Small (Ed.), Arbitration under International Investment Agreements: A Guide to Key Issues, $2^{\text {nd }}$ Ed., Oxford University Press, 2018, p. 420.

19. Arbitration Rules of the United Nations Commission of International Trade Law, Article 21(3) (2010). Available at: <https://bit.ly/2oElbYL $>$ 
1976 was Saluka Investment B.V v. Czech Republic, and it began by addressing whether it had jurisdiction "in principle" over counterclaims under the Netherlands-Czech Republic BIT. The tribunal held that "the jurisdiction conferred upon article 8 of the BIT particularly when read with articles 19(3), 19(4), 21(3) of the UNICTRAL Rules is in principle wide enough to encompass counterclaims" ${ }^{20}$. The tribunal later addressed the issue of connection and held.

a legitimate counterclaim must have a close connection with the primary claim to which it is a response [...] a general legal principle as to the nature of the close connection which a counterclaim must have with the primary claim if a tribunal with jurisdiction over the primary claim is to have jurisdiction also over the counterclaim ${ }^{21}$.

There are two interesting things to remark from this decision, first some tribunals as the Saluka one, are willing the interpret a broad BIT arbitration clause, in favor of counterclaims. Secondly, they interpreted the BIT provision along with the articles of UNCITRAL regarding admissibility of counterclaims. Thus, it can be said that the arbitration rules do play an important factor when assessing the admissibility of counterclaims.

20. Saluka Investment B.Vv. Czech Republic, UNCITRAL, Decisions on Jurisdiction over the Czech Republic's counterclaim, 05/07/2004.

21. Ibídem.

The tribunal denied jurisdiction by applying a strict test of the connection with the original claim requirement. "Other commentators have also criticized the connection required in Klöckner and Saluka as being too demanding, suggesting that a close factual nexus should be enough or that the fact that the counterclaim arises from the same 'investment' as the claim suffices.

We join in these criticisms. The "connection" that is required should be deducted from the ICSID Convention/UNCITRAL Rules and the applicable BIT (such as "subject-matter" or "investment"), nothing suggests that a stricter test than that for jurisdiction or admissibility should be devised (like the Saluka tribunal did). See, P. LALIVE \& L. HALONEN, "On the Availability of Counterclaims in Investment Treaty Arbitration", Czech Yearbook of International Law, 2011, p. 153. 


\subsubsection{Consent}

Consent is the basis of the jurisdiction of the arbitral tribunal and it plays a pivotal role in Investor-State treaty arbitration. Regarding counterclaims there is a general understanding that for them to be admitted they must fall within the jurisdictional scope of the tribunal and for that, party consent is determinative. The first source that tribunal analyzes to address its competence is the IITs or IIAs. "The vast majority of the case law of investment tribunals agrees that the counterclaims must fall within the consent of the parties as expressed in the arbitration agreement based on the relevant IIA"22. There is a logical reason behind this rationale and is that tribunal wants to secure the enforcement of the award and for that purpose, they are extremely careful to not exceed its jurisdiction.

Nevertheless, there does exist a minority that supports the theory that if the parties agreed to a certain set of procedural rules that foresee the possibility of bringing counterclaims, they are expressly agreeing to them as well. Professor REISMAN in Spyridon Roussalis v. Romania, expressed in his dissenting opinion his disagreement with the interpretation that counterclaims must fall within the scope of the parties consent based on an IIA, stating that when the parties to a IIT contingently consent inter alia to ICSID jurisdiction, the consent competent of article 46 of the Washington Convention is ipso facto imported into the ICSID arbitration which an investor elects to pursue ${ }^{23}$.

Professor REISMA's dissenting opinion has since then often been quoted in academic literature and even in arbitral awards, in its relevant part he stated:

22. M. A. Clodfelter \& D. Tsutieva, N. 18, p. 420.

23. D. Atanasova, C. A. Martínez \& J. Ostransky, N. 5, p. 13. 
When the States parties to a BIT contingently consent, inter alia, to ICSID jurisdiction the consent component of Article 46 of the Washington Convention is ipso fact imported to any ICSID Arbitration which an investor then elects to pursue. It is important bear in mind that such counterclaim jurisdiction is not only a concession to the State party; article 46 works to the benefit of both respondent State and investor. In rejecting ICSID jurisdiction over counterclaims a neural tribunal -which was, in fact, selected by the claimant-perforce directs the respondent State to pursue its claims in its own courts where the very investor had sought a forum outside the State apparatus is now constrained to become the defendant ${ }^{24}$ (emphasis added).

The tribunal in Antonio Goetz \& Others and S.A. Affinage des Metaux v. Republic of Burundi25 followed professor REISMAN's dissenting opinion approach asserting jurisdiction over the respondent State's counterclaim on the basis of article 46. In that case the State counterclaimed for damages for failure of the investor to comply with the conditions of an operating license. The Goetz tribunal composed by International Court of Justice (onwards, ICJ) former president Gilbert Guillaume, observed that the article 46 of ICSID Convention is directly inspired by article 80 of the Rules of Procedure of the ICJ which provides "a counterclaim may be presented provided that it is directly connected with the subject matter if the claim of the other party and that it comes within the jurisdiction of the Court" ${ }^{26}$. In this sense, the only requirements that would need to be satisfied for it to hear the counterclaim are two: (i) that it falls within ICSID's jurisdiction and then is notably covered by parties' consent (that falls within the subjects described to be arbitrable in the dispute resolution clause of the BIT); and, (ii) that it is directly related to the object of litigation ${ }^{27}$.

24. Spyridon Roussalis v. Romania, N. 11.

25. Antonio Goetz \& Others and S.A. Affinage des Metaux v. Republic of Burundi, ICSID Case No. ARB/01/2, Award, 21 June 2012.

26. M. A. Clodfelter \& D. Tsutieva, N. 18, p. 422.

27. Ibídem. 
It must be highlighted that the rationale of the tribunal was that Burundi and Belgium by entering their BIT were offering to arbitrate disputes under ICSID Convention and in accordance with the procedure set in those rules, including article 46 which contemplates the possibility of counterclaims. In this sense the investor claimant by refereeing the dispute to arbitration in turn accepted the terms of the offer made in the BIT. Therefore, it is not important that the BIT itself did not contain any provision giving the tribunal jurisdiction to hear counterclaims ${ }^{28}$. In words of professor BRAVIN and KAPLAN stated that article 46 provides for the arbitration of closely related counterclaims "[...] except as parties otherwise agree. Absent such a contrary agreement, the presumption is that counterclaims will be arbitrable. That is why article 46 uses mandatory language" 29 .

Furthermore, the tribunal in Oxus Gold v. Uzbekistan ${ }^{30}$, which was conducted under the UNCITRAL 2010 rules, "recognized a possible exception of counter-claims having a close connection with the investor's claims" leaving the window open to prospect of counterclaims jurisdiction based upon the connection between claims and counterclaims, despite the narrow scope of the BIT's ISDS clause ${ }^{31}$.

It is necessary to highlight that although some tribunals have been more open to consider consent in counterclaims in

28. Ídem, p. 423.

29. M. N. Bravin \& A. B. Kaplan, "Arbitrating Closely Related Counterclaims at ICSID in the Wake of Spyridon Roussalis v. Rumania", TDM, 4, 2012.

30. Oxus Gold v. Uzbekistan, UNCITRAL, Final award, 12/17/2015.

However, the tribunal did not accept the counterclaim because of the limited scope of the arbitration clause found in the BIT: "What seems particularly worth taking attention of as concerns the tribunal's reasoning is its mention of the counterclaims with a close connection to the investor's claims as 'the possible exception' to the finding of the lack of consent in the BIT (para. 948). The tribunal did not develop this idea further, thus, leaving some uncertainty about it. It seems rather ambiguous that, if the tribunal first finds no jurisdiction over the counterclaims based on the consent requirement, it can nevertheless be competent to hear them, even where they are closely connected to the original claims". See, Y. Burova, Counterclaims in Oxus Gold v. Uzbekistan: Is Investor-State Arbitration Still a One-Way Road, CIS Arbitration Forum, 08/16/2016. Available at: <https://bit.ly/2Y3SMRL>

31. M. A. Clodfelter \& D. Tsutieva, N. 18, p. 425. 
the arbitration applicable law or to give a broader interpretation of the dispute resolution clause in the investment treaty, only in four cases have respondent States enjoyed either partial or full success on the merits of their counterclaims. In fact, only in one case an ICSID tribunal has accepted all the Host State's counterclaims on the merits, and that case is Burlington ${ }^{32}$.

\subsection{Basis for allowing Ecuador's counterclaims in Burlington v. Ecuador}

In Burlington v. Ecuador, there was a compromise that allowed the Host Government to submit the counterclaim. This agreement highlights the importance of party consent. The jurisdiction of the tribunal was not challenged since the parties entered an agreement on May 26, 2011, in which the investor consented to the counterclaim and recognized it as the "appropriate forum for the final resolution of the Counterclaims arising out of the investments made by Burlington Resources and its affiliates in Blocks 7 and 21, so as to ensure maximum judicial economy and consistency $^{\prime \prime 3}$. Also the agreement contained other compromises acquired by the parties, it stated as follows:

(i) the tribunal's decision would be final and binding (ii) Ecuador (includingitsemanations, agencies, instrumentalities, subdivisions and controlled corporations) waived its right to file the counterclaims against Burlington, its subsidiaries or any other corporation in the ConocoPhillips Group before 'any jurisdiction whatsoever whether arbitral or judicial, national or international except for this Arbitration'34.

Moreover, the tribunal emphasized in the award, that the parties were in compliance of article 46 of ICSID Convention. The article establishes two conditions for a counterclaim to be admitted: (i) it must arise directly out of the subject-matter of

32. Ibídem.

33. Burlington Resources Inc. v. Republic of Ecuador, ICSID Case ARB 08/5, Award on the Counterclaims, 02/07/2017, p. 38.

34. Ibídem. 
the dispute provided and (ii) they are within the scope of the consent of the parties and are otherwise within the jurisdiction of the Centre. These conditions were met in the case since : (i) the counterclaims arise directly out of the subject-matter of the dispute, namely Burlington's investment in blocks 7 and 21; (ii) they are within the scope of the Parties' consent to ICSID arbitration which is manifested in the agreement just referred to; and (iii) they also fall within the jurisdiction of the Centre as circumscribed by article 25 of the ICSID convention legal dispute arising out of an investment, and nationality requirement ${ }^{35}$.

It is important to remark that from the rationale of the tribunal, it can be interpreted that they imply that the parties by consenting in the treaty to submit the disputes under the ICSID Convention proceeding rules, they were incorporating its provisions regarding counterclaims to the treaty and thus, consenting to them. In other words, the tribunal adopted the view of professor ReIsMAN in Spyridon Roussalis v. Romania ${ }^{36}$ dissent, as well as of the Antonio Goetz $\mathcal{E}$ Others and S.A. Affinage des Metaux $v$. Republic of Burundi ${ }^{37}$ tribunal since both coincide in that "the investor's consent to ICSID was sufficient to imply a consent to counterclaims; there was not need to locate additional or affirmative consent in the underlying BIT" 38 .

Also it is worthy to highlight that the former United StatesEcuador Bilateral Investment Treaty (unilaterally denounced

35. International Centre for Settlement of Investment Disputes Convention (1966), Article 25.

36. The majority's conclusion in Spyridon Roussalis v. Romania was that claimant's mere filing at ICSID was insufficient and of itself to create consent to counterclaims, and that the scope of consent of the parties referred in art. 46 must be determined by reference to instruments external to the Convention, such as the dispute resolution clause contained in the BIT. See, Spyridon Roussalis v. Romania, N. 11.

37. The tribunal reasoned that by concluding the BIT, Burundi accepted that disputes could be submitted to ICSID arbitration according to the conditions and procedures in the Convention, including that counterclaims would be evaluated under the conditions in Article 46; by accepting the offer, Goetz in turn consented; therefore, jurisdiction exists regardless of whether the BIT contains any provision affirmatively providing jurisdiction over counterclaims. See, Antonio Goetz \& Others and S.A. Affinage des Metaux v. Republic of Burundi. N. 25.

38. J. E. KALICKI "Counterclaims by States in Investment Arbitration", Investment Treaty News, 01/14/2013. Available at: <https://bit.ly/2GiiHuW> 
by the Ecuadorean government on 2018), provided a provision, that excluded some types of counterclaims. The BIT on article VI paragraph 7 stated:

In any proceeding involving an investment dispute, a Party shall not assert, as a defense, counterclaim, right of setoff or otherwise, that the national or company concerned has received or will receive, pursuant to an insurance or guarantee contract, indemnification or other compensation for all or part of its alleged damages ${ }^{39}$.

These express exclusions, as discussed ut supra, can be the basis to implicitly admit counterclaims that do not fall in the prohibited categories. It is arguable that this express exclusion of some counterclaims acknowledges in principle that the State has a right to bring other counterclaims, however such provision may not be capable of overcoming a narrowly worded offer to arbitrate ${ }^{40}$. Although the tribunal in Burlington v. Ecuador did not rely on this point to recognize its jurisdiction on the counterclaim, it only supported its jurisdiction on the matter under the rationale that parties had complied with the requirements of articles 25 and 46 of the ICSID Convention, we may argue that this might have been an underlying reason to admit the counterclaim.

Finally, it must be said that another sui generis aspect that distinguishes the case at analysis from the other cases we have discussed, is that there was no objection to the counterclaim by Burlington. And this is due, to another uncommon detail: the parties had agreed not to raise any jurisdictional objection to Ecuador's counterclaims.

The parties to arbitration reached an agreement that they both would commit to the jurisdiction of the tribunal over counterclaims, with the exclusion of jurisdiction of any other

39. United States-Ecuador Bilateral Investment Treaty, entered into force on 11 May 1997, and unilaterally denounced by the Ecuadorean Government on 05/18/2018. Available at: <https:// bit.ly/2h3szvv>

40. M. A. Clodfelter \& D. Tsutieva, N. 18, p. 437. 
arbitration tribunals or national/international courts so as to ensure maximum judicial economy and consistency ${ }^{41}$.

The cases analyzed (Antonio Goetz E Others and S. A. Affinage des Metaux v. Republic of Burundi, Urbaser S.A. and Consorcio de Aguas Bilbao Bizkaia, Bilbao Bizkaia Ur Partzuegoa v. The Argentine Republic ${ }^{42}$ and Burlington Resources Inc. v. Republic of Ecuador) have shifted the trend and contributed to rebalancing the one-sided field of investment arbitration towards the State, by allowing a broader interpretation of article 46 of ICSID both as a valid legal basis to bring counterclaims under IIAs and by recognizing -either implicitly or expressly- the wrongness of understanding BITs or IIAs as only protecting investments trough rights exclusively granted to investors.

\section{The Burlington v. Ecuador Case}

\subsection{Historical background}

Burlington Resources Inc. -the claimant- a corporation created under the law of the State of Delaware, United States in 1988, and recognized for its active exploitation of natural resources, started investing in several oil production facilities in Ecuador ${ }^{43}$. Burlington operated these investments along with its partner Perenco Ecuador Ltd. The claimant was assigned production sharing contracts (onwards, PSCs), in which it was allowed to invest and exploit blocks 7 and 21. According to the

41. E. Burova, Jurisdiction of Investment Tribunals Over Host States'counterclaims: Wind of change?, Kluwer Arbitration Blog, 6 March 2017. Available at: $<$ https://bit.ly/32EQ7NU>

42. In Urbaser S.A. and Consorcio de Aguas Bilbao Bizkaia, Bilbao Bizkaia Ur Partzuegoa v. The Argentine Republic, the tribunal dismissed the claimant's objection to the counterclaim that it had no connection with the original claims as required under article 46 ICSID, however tribunal highlighted that the factual link between original and ancillary claims would suffice to establish jurisdiction over counterclaims. See, Urbaser S.A. and Consorcio de Aguas Bilbao Bizkaia, Bilbao Bizkaia Ur Partzuegoa v. The Argentine Republic, ICSID Case No. ARB/07/26.

43. S. Mustafa \& D. L. Alonso, "Case Report Burlington Resources Inc. v. Republic of EcuadorDecision on reconsideration and the Award", School of International Arbitration Queen Mary University of London International Arbitration Case Law, 2017, pp. 2-3. Available at: <https:// bit.ly/2JyPn5f> 
PSCs, theentire cost-aswellas theoperational risk-wereassumed by the investor in exchange of a share in the oil produced. Also, the PSCs clearly defined the tax regime applicable to Burlington and imposed the obligation to bear any future tax increase on the state-owned oil company Petroecuador by including a correction factor in the production sharing formula ${ }^{44}$.

\subsection{Ecuador's change in Production Sharing Contracts}

In 2006, following a considerable increase in oil price, Ecuador adopted Law 42. This law established that a 50\% tax was imposed to "extraordinary profits" or "windfall profits" made by oil companies. The "extraordinary" or "windfall" profits were defined as those profits resulting from an "unforeseen" rise of oil prices in excess of the price level at the time of the conclusion of the PSCs. The following year, Ecuador increased the tax rate on windfall profits from $50 \%$ to 99\%. Burlington continued paying the taxes from years 2006 to 2008 but made a request for "absorption" by Petroecuador of the additional taxes. Both, Ecuador and Petroecuador ignored the request and the attempts to renegotiate the terms of the PSCs failed. Consequently, Burlington stoped paying the taxes in $2009^{45}$. In an attempt to enforce its tax payments, Ecuador seized and auctioned off Burlington's shares of oil production. Following this incident, Burlington threatened to stop production of oil and as a reaction Ecuador took possession of the production facilities and annulled the PSCs with Burlington by Ministerial Decree.

Burlington initiated arbitration claiming expropriation and in December 2012 the decision on Liability, the tribunal found that Ecuador unlawfully expropriated Burlington's investments. In its decision on Reconsideration and Award,

44. Ibídem.

45. Burlington Resources Inc. v. Republic of Ecuador, N. 33. 
the tribunal quantified the damages owed to Burlington in USD 380 million. In 2011, while Burlington proceedings were initiated, Ecuador raised counterclaims for harm to the environment and certain related infrastructure ${ }^{46}$.

\section{ENVIRONMENTAL COUNTERCLAIMS}

The counterclaims addressed two issues: (i) one regarding the environmental damages; and the other one, (ii) infrastructure damages. In a nutshell, Ecuador alleged that when the consortium abandoned the blocks 7 and 21, they left behind an environmental catastrophe for which they should be held liable. In concrete, Ecuador argued that Burlington was liable under domestic law for soil remediation, groundwater remediation and the abandonment of wells causing mud pits. On the other hand, under the infrastructure counterclaim Ecuador contended that Burlington failed to maintain investment related infrastructure prior to the expropriation.

In this analysis we will focus specifically on the environmental counterclaims raised by Ecuador [4.1]; the factual and legal framework considered by the tribunal [4.2]; the analysis on strict liability [4.3]; remediation under domestic law and the rationale of the tribunal by getting to the decision $[4.4]^{47}$.

\subsection{The 2008 Constitution: a protectionist regime towards the environment}

The 2008 Constitution recognizes nature (or Pachamama) as a legal entity, granting it full protection ${ }^{48}$, and it declared

\footnotetext{
46. M. LeVINE, Ecuador awarded USD 41 million in counterclaims against U.S. oil and gas company Burlington Resources, Investment Treaty News, 09/26/2019, <https://bit.ly/32xJ4Xk> (07/16/2019).

47. Ibídem.

48. Constitution of the Republic of Ecuador, Article 71, RO No. 449, 10/20/2008.
} 
environmental protection as well as the restoration of degraded natural spaces as a matter of "public interest" ${ }^{49}$. Regarding liability, it imposes on oil operators a strict liability regime, under which they are liable on the mere showing of environmental harm under the areas in which they operate. Article 396 establishes: "Responsibility for environmental damage is objective. All damage to the environment, in addition to the respective penalties, shall also entail the obligation to integrally restoring the ecosystems and compensating the affected persons and communities"

Under strict liability ${ }^{51}$, the Constitution establishes that: (i) the burden of proof of the non-existence of harm falls on the operator; (ii) the operator is only responsible for the harm caused by him; and, (iii) there is no statute of limitations on environmental damages actions. Thus, the State has no obligation to prove either that the operator was at fault nor that there exists causation between a breach of their duty of care and the environmental harm. Ecuador alleged that the Constitution applied to all the environmental harms discovered after 2008, regardless of when they were actually committed.

Ecuador alternatively alleged that the protection of the nature was a matter of public order as established in the Constitution, and that according to the Supreme Court of Ecuador in the case A. Baquerizo G.C. Ltda v. Shulton Inc ${ }^{52}$ rules that regulate public order matters can be applied retroactively. This argument was made to justify the application of the 2008 Constitution retroactively. Ecuador stated that even if this argument is not taken in consideration, the 1998 Constitution also provides for strict or objective liability regimen for

49. Ídem, Art. 14.

50. Ídem, Art. 396.

51. Ídem, Art.397, RO No. 449, 10/20/2008.

52. Supreme Court of Justice, Baquerizo G. C. Ltda. v. Shulton Inc., Third Civil and Mercantile Chamber, Judicial Gazette 12, 09/25/2003. 
environmental issues, with the only difference in the burden of proof and statute of limitation. Supporting this idea, the case law from the Supreme Court in Delfina Torres v. Petroecuador ${ }^{53}$ and Aguindav. Chevron ${ }^{54}$ in 2002, according to Ecuador's defense establishes an exception for extractive industries operators: once the environmental harm is proven, the only way for the operator to scape liability is either by proving force majeure or third party fault.

According to Arturo VAlencia ZeA, a Colombian scholar quoted by the Supreme Court of Justice in the case Delfina Torres v. Petroecuador, which then identified the elements of strict liability showing that it is for the alleged tort-feasor to prove that he or she did not cause the harm:

Hence, the need arises to promulgate a new type of liability for this type of harm, eliminating the criteria of fault through strict liability or the establishment of an absolute presumption of such. The owner of an exploitation or industry should respond directly for harm caused by the referenced industry or exploitation, and he may only exempt himself from liability if he shows that the harm did not arise from the exploitation, and arose instead from a foreign act (force majeure, fault of a third party or the fault of the victim itself $)^{55}$.

Accordingly, the following elements are characteristic of the strict liability regime for environmental harm under Ecuadorian law as established in Delfina Torres v. Petroecuador ${ }^{56}$ case:

(i) the plaintiff must prove harm connected to the defendant's activities;

(ii) fault is not required; and

53. Supreme Court of Justice, Comité Pro Mejoras Barrio Delfina Torres vda. de Concha v. Petroecuador, Petrocomercial and their affiliates ("Delfina Torres v. Petroecuador"), Case No. 229-03, 10/29/2002, RO No. 43, 03/19/2003, p. 21. Available at: <https://bit.ly/2YVf3yl >

54. National Court of Justice, María Aguinda Salazar et al. v. Chevron Corporation ("Aguinda v. Chevron"), Civil and Mercantile Chamber, 11/12/2013.

55. Free translation. Supreme Court of Justice, Delfina Torres v. Petroecuador, N. 51.

56. Ibídem. 
(iii)causation is presumed, the defendant being exonerated if he or she proves that the harm was caused by force majeure, the victim or a third party.

Thus, if the tribunal did not recognize the 2008 Constitution standard of liability, the one to be applied was the 1998 Constitution $^{57}$ according to the interpretation of the Supreme Court in the Delfina Torres v. Petroecuador case, in which case Burlington would have to prove in order to scape liability, that the harm was caused by force majeure or a third party.

Regarding the issue of statutes of limitation, Ecuador argued that claims for strict liability are subject to the limitation set forth in article 396(4) of the 2008 Constitution, meaning that they are imprescriptible. However, it alleged alternatively, that even if article 2235 of the Civil Code ${ }^{58}$ were to apply, the period would start to run once the harm is discovered, which is after the consortium abandoned the blocks in July 2009. Ecuador adds that its argument is reinforced by Burlington's concealment policy and lack of reporting and that by acquiring its interest in the blocks, Burlington contractually took over the environmental liabilities of prior operators.

\subsection{Legal framework to resolve environmental counterclaims}

The first issue that the tribunal addressed was to determine what was the applicable law to the environmental claims. To the procedural aspect of the arbitration, the ICSID

57. Free translation. "The State, its delegates, and concessionaries, shall be responsible for the environmental damages in the terms of article 20". Political Constitution of the Republic of Ecuador, Article 91, RO No. 1, 08/11/1998.

Free translation. "The State institutions, its delegates and concessionaries, shall be obliged to indemnify the particulars for the perjuries suffered as consequences of their deficient public services or the actions of their employees made during their functions. The institutions will have a right to repetition and to make effective the responsibility of their functionaries and employments for judicially declared gross negligence and deceit [...]". Political Constitution of the Republic of Ecuador, Article 20. RO No. 1, 08/11/1998.

58. Civil Code, Art. 2235, RO Sup No. 46 06/24/2005

Free translation. "Art. 2235.- The actions that grant this title due to damage or fraud prescribe in four years, counted from the commission of the act". 
Convention Rules were undisputedly the applicable ones. On the other hand, the applicable law to the substance of the matter, according to the tribunal was the Ecuadorean law. However, Ecuador's position was that the law to be applied was not Ecuadorian contract law, but Ecuadorean tort law. Nevertheless, Ecuador relied on the PSCs provisions to argue the strict liability applicability.

The tribunal according to article 42 of the ICSID Convention, shall decide the dispute (i) "in accordance with such rules of law as may be agreed by the parties"; absent which (ii) "the tribunal shall apply the law of the [Host State] [...] and such rules of international law as may be applicable" 59 . Here, Ecuador brought a tort action, and neither party argued that the choice of (Ecuadorian) law in the PSCs encompasses torts. The PSCs choice of law did not contain any reference to tort law. However, the tribunal decided to apply Ecuadorian tort law, not as the law chosen by the parties under the first leg of article 42(1) of the ICSID Convention, but as the law of the Host State under the second leg of that provision.

The relevance of this distinction is that, under the second leg, international law also "may be applicable". The tribunal decided to sustain its decision under this section since it gave it the discretion and freedom to apply either municipal law or international law depending on the type of issue resolved. In the case that there is any particular matter that may call for application of international law, the tribunal can decide on its applicability. Thus, the tribunal decided to apply Ecuadorian law to the environmental counterclaims, reserving itself discretion to apply international law to any applicable matter.

59. International Centre for Settlement of Investment Disputes Convention (1966), Article 42. 


\subsection{Liability in environmental counterclaims}

The tribunal decided that the Ecuadorean Constitution and its strict liability regime did not apply retroactively to the present case. The tribunal held that the applicable regime was the one foreseen in the Constitution of 1998, which established a fault-based regime under which the defendant could scape liability by demonstrating their due diligence in trying to avoid harm. However, as seen above, case-law of the Superior Court had established an exception to this liability regime to certain areas including oil field operations. "At least since 2002, the tribunal held, Burlington could only scape liability for proven environmental harm by pleading force majeure or showing that a third party had caused the harm"60. In other words, this exception applicable to the oil exploitation provided for a strict liability regime.

Under the former strict liability regime, the plaintiff must prove harm connected to the defendant's activities, the existence of fault is not required and causation between the harm and the defendant's activity is presumed. Therefore, once Ecuador had proven that the harm reasonable related to Burlington's risky activities, Burlington could only scape liability either by proving that the harm was caused by force majeure or by a third party.

Regarding the issue of time bar to interpose the claim, the principle of statute of limitations or non-applicability of the 2008 Constitution did not applied retroactively. However, the tribunal determined that a four-year time bar in domestic law did apply to claims under the pre-2008 law, and thus to the present case, but the time must be counted since the date of the discovery of the damage rather than from the date the damage occurred. Consequently, the counterclaims were not time barred.

60. J. Hepburn, Analysis: successful counterclaim in Burlington v. Ecuador breaks new ground, International Arbitration Reporter, 02/13/2017, p. 3. 


\subsubsection{Meaning of environmental harm}

After determining the general issues, the tribunal addressed the issue of the meaning of environmental harm. While Burlington alleged that environmental harm must be understood in reference with the "permissible limits" set out in applicable regulation, Ecuador alleged that it must be defined by "background values" or the environmental conditions as they were before the human interference. Moreover, if the scenario of permissible limits was to be adopted it had to define whether the relevant limits are those applicable to industrial or agricultural land use (as argued by Burlington) or to sensitive ecosystems (as argued by Ecuador in the alternative).

The tribunal emphasized the significant monetary value that the distinctions hold. While Ecuador was claiming \$2.5 billion in remediation costs to restore the oilfield background values, it was only claiming an alternative $\$ 790$ million to restore permissible limits for lands classified as sensitive ecosystems' under domestic law ${ }^{61}$.

On its analysis the tribunal recognized that the 2008 Constitution mandates the parties that caused the contamination to fully restore the damages, and to take the environment to its initial state. In this sense, the tribunal recognized that the Constitution mandates full restoration but does not define what is environmental harm. Thus, the tribunal sustained that there was no support for Ecuador's argument that the notion of full reparation or full restoration under the 2008 Constitution mandates a return to pre-human conditions or, as Ecuador puts it, the return to a state of the environment "prior to any form of contamination". In the end, Ecuador's reliance on the notion of full restoration sheds no light on the notion of environmental harm. The question remained

61. C. M. Woow \& G. Castelan, Environmental and Human Rights Considerations for International Energy Companies, p. 3. Available at: <https://bit.ly/2NXHP01> 
whether relying on permissible limits to define environmental harm would be contrary to the 2008 Constitution as Ecuador contends ${ }^{62}$.

Ecuador adopted a definition of environmental harm in the Environmental Management Law (Ley de Gestión Ambiental or LGA, by its Spanish initials) in 1999: "any significant loss, decrease, detriment or impairment to the preexisting conditions in the environment or one of its components. It affects the functioning of the ecosystem or the renewability of its resources"63 (free translation). This LGA, was followed shortly by revisions to the permissible limits in Environmental Regulation for Hydrocarbons Operations of Ecuador (RAOHE) in 2001 and by the adoption of limits in United Text of Secondary Environmental Legislation (TULAS) in 2003. The tribunal noted that the LGA not only provided a definition of environmental harm, it also refers to permissible limits. Article 1 states that the LGA establishes principles and guidelines of environmental policy, determines obligations and responsibilities, and "indicates the permissible limits, controls and sanctions in this matter". Moreover, article 33 stipulates that "environmental quality parameters" shall be established as "instruments for the application of environmental norms", which shall be "governed by the respective regulation". This provision tends to support the proposition that RAOHE and TULAS refine and implement the general provisions of the LGA $^{64}$.

Consequently, the tribunal resorted to RAOHE and TULAS, to define harm under the LGA. Hence, the limits set out in these regulations established when impacts become significant, and thereby become harm, thus allowing the inference that these limits determine when the functioning of

62. Burlington Resources Inc. v. Republic of Ecuador, N. 33, pp. 52-54.

63. Ley de Gestión Ambiental, Definition glossary, RO Sup No. 418, 09/10/2004.

64. Burlington Resources Inc. v. Republic of Ecuador, N. 33, p. 279. 
the ecosystem or the renewability of its resources are affected. In other words, any exceedance of applicable limits triggers extra contractual civil liability and the ensuing obligation of full restoration back to these limits, independently from parallel administrative liability and possible sanctions ${ }^{65}$.

After examining the local laws, the tribunal concluded that regulatory limits rather than background values should apply to determine if there was an environmental harm. The tribunal decided that environmental harm is defined by reference to regulatory criteria. In other words, an oilfield operator could not be considered to have caused environmental harm if permissible limits were observed, since precisely these permissible limits allow determining when a negative impact crosses the threshold of harm ${ }^{66}$. The tribunal relied on the regulations regarding the permissible limits provided in TULAS, since the ones provided in RAHOE weren't clear. Article 4(1)(3)(3) of TULAS provided the formula on how to calculate excess of permissible limits:

The Environmental Control Entity shall adopt the following evaluation criteria: The regulated entity must establish the background or reference value of the parameter of interest present in the soil67. The regulated entity shall determine the present or current concentration of the parameter under study in the affected area. It shall then proceed to compare the obtained results for the concentration present in the soil against the background values. In general, it is considered that a present concentration greater than three times the background value for the soil denotes contamination that requires immediate

65. Ídem, p. 392.

66. C. M. Wood \& G. Castelan, N. 61, p. 3.

67. The regulation provided that in order to determine the reference value, they must collect from 5 to 20 samples in the areas immediately outside of the area of study, with no local contamination. The mean value of this samples will be the one considered as the background value. Then the comparison should be done between that background value, and the value of the samples gathered in the contaminated areas. If the result is three times greater, it will be considered as an excess of the permissible limits and therefore as environmental harm. 
attention on the part of the Environmental Control Entity ${ }^{68}$ (emphasis added).

Consequently, for the tribunal to determine the level of impermissibleenvironmental harm in thelight of the regulatory criteria, they needed to conduct a comprehensive examination of harm and cost remediation of 40 sites distributed along the two blocks explored by Burlington. For this purpose, the tribunal did a site visit, in which it found environmental harm and a need for remediation at all sites.

\subsection{Reparation of damages in environmental claims}

In order to determine the remediation costs and the compensation costs, the tribunal visited the sites to recover and review all the evidence regarding the existence of environmental degradation. One part of their tasks was the determination of each area as an "industrial", "agricultural" or "sensitive ecosystem" since each classification has a different applicable standard ${ }^{69}$. It is notable that whenever there was a doubt on the classification of the sites, the tribunal "adopted the most protective standard in conformity with the principles of precaution 'in dubio pro natura' contained in the Ecuadorean Constitution ${ }^{70}$.

The tribunal found environmental harm and need for remediation at all sites. The tribunal held that the following

68. Burlington Resources Inc. v. Republic of Ecuador, N. 32, pp. 139-140.

69. Consequently, the tribunal developed the following guidelines to assess land use at any given site:

i. Platforms in operation on or after the date of expropriation have been classified as industrial, as explained above.

ii. Formally designated protected forests are classified as sensitive ecosystems (except for platforms), regardless of other current uses.

iii. Where platforms are completely surrounded by primary or secondary forest, the tribunal classified the forested areas as sensitive ecosystem.

iv. Where areas surrounding the platform are largely cleared, the tribunal classified the land use of those areas as agricultural.

v. Where multiple land uses may apply to a single site the tribunal looked more specifically at the sampling locations to determine the land use in that specific area.

70. Burlington Resources Inc. v. Republic of Ecuador, N. 33. 
remediation technologies appear the most appropriate in those circumstances: ex situ-controlled confinement of soils contaminated with heavy metals; ex situ bioremediation of soils contaminated with crude; and ex situ soil washing for soils contaminated both with crude and heavy metals ${ }^{71}$. For most sites, the valuation was placed at less than USD 1 million. However, there were three cases, one of soil contamination, one of mud pit and one of water contamination in which it was awarded costs exceeding USD \$ 5 million per site ${ }^{72}$.

This withoutdoubt, is a favorableprecedent to the protection of the environment as well as the public interest matters of the States. However, the tribunal did not discuss other reparation methods, such as punitive damages, disregarding that the Ecuadorean Constitution foresees the precautionary principle and the trend should be towards a broader protectionism of the environmental rights. The Investor should have prevented contamination and environmental damages; they should not be responsible for the amount of their wrongdoings but also should pay for the lack of due care.

In this sense in the case Costa Rica v. Nicaragua ${ }^{73}$, the first case in which the International Court of Justice recognized environmental damages due to violations of International Environmental Law, Judge CANÇADO established, in accordance with the precedents of the Inter American Human Rights Court: "one should also keep in mind, besides restitutio in integrum and compensation, distinct forms of reparation, such as satisfaction, rehabilitation, and guarantee of non-repetition of the wrongful acts"74. In the same line of reasoning, Judge Bhandari's

71. Ídem, pp. 196-197.

72. M. LeVINE, N. 46, p. 2.

73. International Court of Justice, Costa Rica v. Nicaragua, 04/17/2013.

74. M. DA SILVA, "Compensation Awards In International Environmental Law: Two Recent Developments", New York University Journal of International Law and Politics, Vol. 50, No. 4, 2018, p.1426. 
separate opinion discusses the role of the precautionary principle in international environmental law and the possibility of -awarding punitive damages as a measure of deterrence of future harm. He states that " $[t]$ he growing awareness of the need to protect the natural environment is also shown by the crystallization of the precautionary approach into a customary rule of international law" ${ }^{\prime 75}$.

It must be recognized the Tribunal made a good job by applying the domestic law and enforcing the protectionist environmental provisions of the Ecuadorean Constitution and domestic regulations, however since they had the discretionary power to include even international law in deciding the substantive issues according to the article 42(2) of the ICSID Convention, they could perfectly had incorporated international law principles such as the precautionary, that it is also recognized in the Ecuadorian Constitution, to elevate the standard from a "de minimis" to a broader international protection level. This precautionary principle goes in hand with the customary international law obligation to conduct an environmental assessment in regard of any large scale project. This environmental impact assessment may be expected to identify potential harm that an investor must avoid or mitigate to the extent that he has "caused", "contributed" or been "directly linked" to such adverse impacts" ${ }^{76}$. Since this are the first decisions, we must hope that this baby steps, gain more force in the following decisions awarding not only compensatory damages but also punitive damages for the lack of due care, wrongdoings or omissions of the Investors.

75. Ídem, p. 1426.

76. J. Amado, J. Shaw \& M. Doe Rodriguez, Arbitrating the Conduct of International Investors, Cambridge University Press, 2018, p. 140. 


\section{Ecuadorian Bit Models: A broader protection for THE ENVIRONMENT}

One of the last acts of the former government on 16 May, 2017 was the denunciation of several investment treaties with countries such as: Argentina, Bolivia, Canada, Chile, China, United States, Spain, Italy, Netherlands, Perú y Switzerland, after the Constitutional Court declared their unconstitutionality in independent decisions. A Commission named CAITISA, is in charge of drafting the New Model of Investment Treaty that Ecuador will negotiate, there has not been any official result, however a preliminary draft was circulated.

This draft contained interesting chances, for instance the ones that concern us are the following: first, it expressly recognizesobligations to theinvestors, suchas "compliancewith all domestic law applicable as well as a duty to respect human rights and environmental rights recognized internationally as well as in the domestic legislation of the Host State in each of the supply chain and investment processes. The violation of human or environmental rights will gran the Host State the right to request the proportional integral reparation according to international law and domestic law" ${ }^{\prime \prime 7}$. Second, it establishes the right of the State to commence any arbitral proceeding, it does not name anything regarding counterclaims, but the logic should be that if it has the right to sue of it must have the right to counterclaim. Finally, it does not contemplate indirect expropriation and it contemplates a formula to calculate compensation in case of direct expropriation.

77. Ecuadorean New Model Investment Treaty, Article 20. Still on drafting and negotiation phase. 


\section{Conclusion}

We have observed a positive shift in the Investment State arbitration tribunals in the last decade, in which it looks like some of them, have recognized the asymmetry and imbalance in Investor State Dispute Resolution. While tribunals in the past century were reluctant to admit counterclaims if there was no express provision in the BIT, recent tribunals such as the Goetz v. Burundi, Urbaser v. Argentina, and Burlington v. Ecuador, have been willing either to interpret some arbitration clauses more broadly or to recognize consent in the acceptance of a particular arbitration set of rules that contemplates the possibility of counterclaim.

These analyzed precedents in which tribunals have recognized jurisdiction to hear counterclaims even tough not expressly contemplated in the IAAs or IITs, as well as respected and upheld domestic law as well as national Constitutions to protect the Host State environmental and even human rights, reflects a positive change in ISDS. For Investment arbitration to survive, new IIAs and IITs, must follow the trend and follow the example of USMCA, COMESA and Ecuador, in order to rebalance the playing field by recognizing the right for Host States to sue, counterclaim, impose obligations of due care and environmental and human right responsibilities to Investors under the framework and protection of the Investment Treaties. New winds are blowing, hopefully they will keep in flowing in the right track. 